\title{
Ki-67 Positive Cells Less than 10 Percent
}

National Cancer Institute

\section{Source}

National Cancer Institute. Ki-67 Positive Cells Less than 10 Percent. NCI Thesaurus. Code C161839.

A semi-quantitative microscopic finding indicating that less than 10 percent of the cells in sample are detected following staining using an anti-Ki-67 antibody. 